\title{
How does transportation hub status promote the urban economic development? _ the mediating effect analysis of innovation
}

\author{
Baosheng Zhang ${ }^{1 *}$ \\ ${ }^{1}$ School of Economics and Management, Shangqiu Normal University, Shangqiu, China
}

\begin{abstract}
A good traffic hub position has important significance for the development of a city, but it also strengthens the polarization effect, diffusion effect and return effect of the regional central cities for other cities. Does the development of urban hub economy strengthen or weaken these effects? Does hub effect also need other conditions to promote urban economic development? From the perspective of technological innovation, this paper analyses the mediating effect of technology absorption and innovation in the process of urban transportation hub promoting economic development. It is found that the people flow effect in the hub effect can better promote the economic development of cities through the mediating role of knowledge absorptive and innovative ability. In the influence of logistics effect on urban economic development, the mediating role of knowledge absorptive and innovative ability is not significant.
\end{abstract}

\section{Introduction}

Transportation infrastructure is a prerequisite for economic development ${ }^{[1]}$. It promotes urban economic development by improving production efficiency ${ }^{[2]}$, accelerating regional economic integration, and promoting population spatial agglomeration ${ }^{[3]}$. Since the reform and opening up, China's transportation infrastructure investment and the length of transportation routes has increased rapidly. In 2018, the length of railways in operation, highway and regular civil aviation routes has increased from $51,700 \mathrm{~km}, 890,200 \mathrm{~km}$ and $148,900 \mathrm{~km}$ in 1978 to $131,700 \mathrm{~km}, 4,846,500 \mathrm{~km}$ and $8,379,800 \mathrm{~km}$ respectively (Fig.1). Transportation time between cities is constantly shortening, and each urban government is committed to be a transportation hub of the region. In 2015, in order to play a basic and leading role of the circulation industry, the Ministry of Commerce of China issued the National Circulation Node City Layout Planning (2015-2020), identifying 37 national circulation node cities and 66 regional circulation node cities. At the same time, in order to promote coordinated development of regional economies, China government issued the Opinions of the State Council on Establishing a More Effective New Mechanism for Regional Coordinated Development on November 18, 2018, which put forward a new model in which central cities lead the development of urban agglomerations and urban agglomerations drive regional development. In the process of urban agglomeration development, each city seeks development opportunities brought by hub effect and develops hub economy through the construction of transportation infrastructure.
However, in this process, there are polarization effect, expansion effect and return effect between the central city and other cities ${ }^{[4]}$. Does the development of hub economy strengthen or weaken these effects? Does hub effect need other conditions to promote urban economic development? From the perspective of technological innovation, this paper analyzes the mediating effect of technology absorption and innovation in the process of urban transportation hub effect promoting economic development. In the first part, the basic hypothesis was given through literature review. In the second and third parts, PIS-SEM method was used to test the basic hypothesis, and finally the conclusion was given.

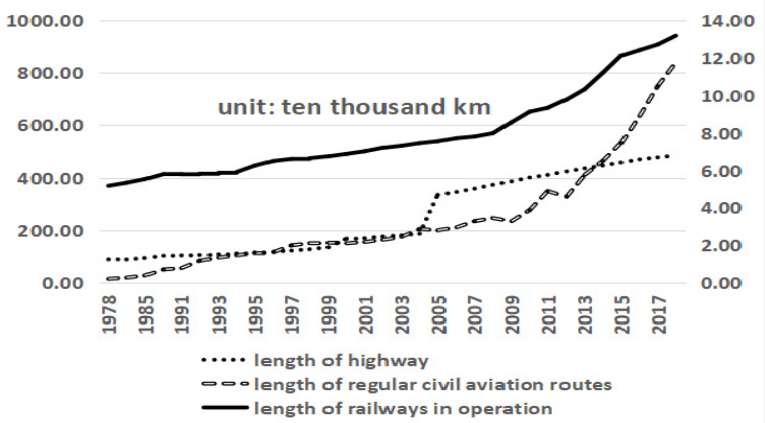

Fig. 1. Length of transportation routes of China over the years before 2018

(Length of Railways in operation corresponds to the sub-axis on the right. Data source: China Statistical Yearbook, 2019)

\section{Literature review}

The famous urban economic theorist Jacobs argues that cities play a central role in the process of innovation,

\footnotetext{
* Corresponding author: zhangbaos1124@163.com
} 
entrepreneurship and economic growth, the urban economic development is not dominated by a single production function, and its role in innovation is mainly based on scope economy and diversity ${ }^{[5]}$. City is a platform for gathering talent, information and material capital, and can make them recombine into new forms of production, create new products and promote economic growth. That is to say, urban economic growth focused by Jacobs is not just a process achieved by specialization and expanding output, but one driven by innovation. Lucas argues that it is just because the city gathered all kinds creative talents which makes 'recipes' with capital and land, promote the economic growth ${ }^{[6]}$. City is a platform for making the recipes. Olivier Crevoisier analyzed the mediating effects of ILSs (Interaction and Learning Sites) between urban dynamics and production system (innovation) dynamics in the study of the relationship between innovation and the city ${ }^{[7]}$. In a city, ILSs establishes links between urban participants and enterprises, provides innovative resources and innovative environments, especially new resources in proprietary technologies, and ensures that these resources interact with each other in the process of innovation and can be used and developed ${ }^{[8]}$. Boyd Cohen et al. introduced the concept of Urbanpreneur Spiral, and argues that the interaction among democratized innovation, collaborations and urbanization, has driven the urban innovation and entrepreneurship, thereby promoted the urban economic growth of the city ${ }^{[9]}$.

H1: Innovation helps to promote the development of urban economy

As an innovation platform, urban infrastructure, especially transportation infrastructure, plays an important role in the accumulation of urban innovation elements. Meanwhile, as a prerequisite for economic development, the relationship between transportation infrastructure investment and economic growth has always been the focus of economics researchers ${ }^{[10]}$. Many scholars have analyzed whether the improvement of urban traffic condition can improve its innovation ability and economic development level. Because the role of transportation infrastructure in economic growth requires the synergistic influence of institutional environment, human capital, science and education technology and other factors, the spatial spillover effect of transportation infrastructure is complex. Diffusion effect produced by transportation infrastructure network properties include the positive and negative spatial spillover. Positive spatial spillover makes the regions with fast economic growth drive the regions with slow growth, while negative spatial spillover makes the production factors flow more conveniently to the developed regions, which exacerbates the economic recession in the backward regions ${ }^{[11]}$. That is to say, the accessibility, centrality and intermediacy of the transportation hub city improve the flow speed of innovation factors, which has dual effect on the development of a city. The positive effect promotes the agglomeration of production factors in a city, while the negative effect intensifies the run off of them.

In terms of positive effect, it mainly includes economic effect and innovative effect. For economic effects, Feng and Xu made a literature review on the role of transportation infrastructure in economic growth and summarized it into five aspects ${ }^{[12]}$ : external spillover effect, efficiency improvement effect, industrial agglomeration effect, regional development effect and modernization effect. The opening of the high-speed railway improves the accessibility of the region, makes small cities closer to the central city, improves the potential of the regional market and the process of regional integration, and provides the possibility for the manufacturing migration of central cities and the manufacturing agglomeration of small and mediumsized cities ${ }^{[13]}$. According to Liu and Li, the role of highspeed railway in promoting regional economic growth is mainly reflected in increasing capital input, promoting population migration, improving total factor productivity and the agglomeration effect of cities ${ }^{[14]}$. Li et al. found that the opening of high-speed railway promoted the flow of capital factors, optimized the allocation of capital factors, and improved the productivity of enterprises, but its influence had the heterogeneity of location, industry and ownership ${ }^{[15]}$. For innovation effect, Okabe and Sands found in their research on Shinkansen in Japan that high-speed railway, as a passenger transport tool, shortened travel time and promoted the times of face-to-face exchanges in R\&D and educational activities ${ }^{[16]}$. Chen and Hall believed that the construction of high-speed railway in Britain accelerated the flow of talents and promoted the exchange of knowledge ${ }^{[17]}$. Since knowledge overflow is a decreasing function of spatial distance ${ }^{[18]}$, the agglomeration degree of knowledge-intensive practitioners is significantly higher in an hour economy circle than in regions with a longer distance ${ }^{[19]}$ Liu believes that high-speed railway promotes the innovative development of cities by accelerating the knowledge spillover in the process of talent flow and enhancing the interaction between innovation participants and innovation elements ${ }^{[20]}$. Wei and $\mathrm{Li}$ found that during the period from 2009 to 2016, due to the influence of the high-speed railway network in the Yangtze River Delta, the knowledge spillover effect had a promotion effect on the agglomeration of the tertiary industry ${ }^{[21]}$. Yang and Li used DID method to test the influence of the opening of high-speed rail on the urban innovation level, and found that it can significantly enhance the innovation level of smaller cities, but not significant to larger provincial capital cities ${ }^{[22]}$. Du and Peng found that the opening of high-speed rail promoted the attraction of cities for senior talents, especially for cities without airports $^{[23]}$. It can be seen that the hub effect of transportation infrastructure strengthens the concentration of human capital, improves urban technology absorptive capacity, and promotes regional innovation capacity ${ }^{[24]}$, thus further promotes urban economic development. Therefore, the second, third and fourth assumption are:

$\mathrm{H} 2$ : The flow of people in the traffic hub effect is the premise of human capital agglomeration, which enhances the urban knowledge absorptive capacity. 
H3: The improvement of urban knowledge absorptive capacity promotes the innovation capacity.

H4: The improvement of urban knowledge absorption capacity promotes knowledge exchange and thus promotes urban's economic development.

In terms of negative effects, some scholars believe that the opening of high-speed rail produces a 'siphon effect' on surrounding non-regional central cities or leads to 'polarization effect' which widen the regional gap, the development of small cities will be held back ${ }^{[25]}$. Gutierrez et al. argued that the development of the highspeed railway network, on the one hand, would produce accumulative effect in the central region, and would also exacerbate the gap between the peripheral cities and the central hinterland ${ }^{[26]}$. The higher the urban TFP is, the greater the rate of return of innovative elements will be, and the greater the 'siphon effect' on neighboring cities will be ${ }^{[27]}$. At the same time, with the aid of good hub position, compared with cities with low absorptive capacity, cities with high knowledge absorptive capacity are more likely to absorb more human capital, promote the transfer of existing technologies, and improve the innovation ability of cities ${ }^{[28]}$. That is to say, whether the urban transportation hub status matches its innovation ability and economic development level depends, to a certain extent, on the comparison of total factor productivity and technology absorptive capacity between cities. In other words, knowledge absorptive capacity and technological innovation capacity play an intermediary role in the impact of transportation hub effect on urban economic development.

Then, does the hub effect of transportation infrastructure ultimately promote or inhibit the development of cities? It depends on the contrast between positive and negative effects. The positive effect is multifaceted, while the negative effect is mainly manifested as the 'siphon effect', which is unilateral. Therefore, it can be considered that the positive effect is larger than the negative effect, and in the end the hub effect of transportation infrastructure can promote urban economic development on the whole. The hub effect will be considered from the flow of people and objects here. For objects, both the inflow and outflow of products or materials are beneficial to the development of cities. For people, it is different, because the outflow of human capital is different from the inflow of it. The outflow is adverse to economic development. Therefore, two hypotheses are:

H5a: The influence of people flow in hub effect on urban economic development depends on the urban knowledge absorptive and innovative ability.

$\mathrm{H} 5 \mathrm{~b}$ : The increase of logistics effect in hub effect can promote urban economic development.

In urban innovation, in addition to the key role of enterprises, assets, markets, institutions and networks

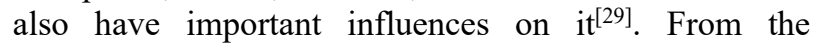
perspective of the market, the increase of the product flow in the transportation hub enhances the business efficiency and profitability of enterprises and further promotes enterprise and urban innovation. From the perspective of assets, the development of urban logistics industry is often accompanied by the increase of transportation infrastructure investment, which provides a good hardware environment for urban innovation. At the same time, the development of information technology promotes the technology and business model innovation in the logistics industry, and further promotes the development and technological progress of related industries. Therefore, the sixth hypothesis is:

H6: The logistics effect is conducive to promoting urban innovation.

\section{Model specification, methods and data}

In this paper, PLS-SEM method was used to analyze the research hypothesis proposed above. Compared with other methods, the PLS method has more advantages in terms of simultaneous processing of more variables and small sample support, and it does not need to assess whether the original data conforms to the normal distribution ${ }^{[30]}$. The main analysis software used here is SmartPLS3.3.2.

In the model, the hub effect of urban transport infrastructure is represented by two latent variables, transportation capacity of passengers (PAS) and transportation capacity of freight (FRE). Other three latent variables include urban innovation capacity (INN), technology absorption capacity (ABS) and urban economic development (EDE). For each latent variable, the corresponding explicit variable is set. PAS includes three explicit variables, namely Highway Passenger Traffic(PAS1), Civil Aviation Passenger Traffic(PAS2) and Number of Trains to and from the City (PAS3). Since the inter-city water passenger volume in China is small and the statistical data are incomplete, Water passenger capacity is not taken into account here. FRE includes Highway Freight Traffic (FRE1), Waterway Freight Traffic (FRE2) and Civil Aviation Freight Traffic (FRE3). INN includes R\&D Internal Outlay (INN1) and Number of Patent Authorizations (INN2). ABS includes R\&D Personnel(ABS1), Expenditure for Education(ABS2) and Undergraduate in Regular HEIs (ABS3) . EDE includes GDP per capita of municipal district (EDE1), Local General public budget Expenditure (EDE2), Total Fixed Assets of Industrial Enterprises above Designated Size of municipal district (EDE3), Total Retail Sales of Consumer Goods of municipal district (EDE4) and Export Volume of goods of total city (EDE5).

The data is from 243 cities in Chinese Mainland in 2018, among which the date of data PAS3 is on December 31, 2018, and from AITIELU ${ }^{[31]}$. Other data are from The Statistical Yearbook of Chinese Cities (2019).

\section{Results}

\subsection{Evaluation of measurement model}

Table 2 shows the results of the reliability, validity statistics and correlations. Firstly, all the outer loadings 
are above 0.7 and significant at 0.01 level. These indicate that the construct explains more than 50 percent of the indicator's variance, thus providing acceptable item reliability. Second, all values of Cronbach's alpha are greater than $0.70^{[32]}$, suggesting acceptable reliability. Third, two additional indicators - the composite reliability $(\mathrm{CR})$ index and average variance extracted (AVE) - were calculated to assess the reliability of the scale. Both indicators exceeded the recommended minimum values of 0.7 and $0.5^{[33]}$, respectively confirming the scale's reliability. To effectively assess the validity of the measurement model, discriminant and convergent validity were assessed. From the values of AVE and CR in Table1, show that the model meets the criteria for assessing convergent validity. In addition, because the square root of each AVE is greater than the correlations between the constructs with reflective items, all the constructs in this study have discriminant validity.

Table1. Reliability, validity statistics and correlations

\begin{tabular}{|c|c|c|c|c|c|c|}
\hline & & $\begin{array}{l}\text { Outer } \\
\text { loadings }\end{array}$ & CR & $\begin{array}{l}\text { Cronbach's } \\
\alpha\end{array}$ & AVE & $\begin{array}{l}\text { Discriminant } \\
\text { validity } \\
\text { (Yes/No) }\end{array}$ \\
\hline \multirow{3}{*}{ ABS } & ABS1 & $0.962 * * *$ & \multirow{3}{*}{0.93} & \multirow{3}{*}{0.882} & \multirow{3}{*}{0.81} & \multirow{3}{*}{ Yes } \\
\hline & ABS2 & $0.949 * * *$ & & & & \\
\hline & ABS3 & $0.783 * * *$ & & & & \\
\hline \multirow{5}{*}{ EDE } & EDE1 & $0.638 * * *$ & \multirow{5}{*}{0.93} & \multirow{5}{*}{0.904} & \multirow{5}{*}{0.73} & \multirow{5}{*}{ Yes } \\
\hline & EDE2 & $0.932 * * *$ & & & & \\
\hline & EDE3 & $0.947 * * *$ & & & & \\
\hline & EDE4 & $0.938 * * *$ & & & & \\
\hline & EDE5 & $0.780^{* * *}$ & & & & \\
\hline \multirow{3}{*}{ FRE } & FRE1 & $0.647 * * *$ & \multirow{3}{*}{0.84} & \multirow{3}{*}{0.710} & \multirow{3}{*}{0.64} & \multirow{3}{*}{ Yes } \\
\hline & FRE2 & $0.843 * * *$ & & & & \\
\hline & FRE3 & $0.881 * * *$ & & & & \\
\hline \multirow{2}{*}{ INN } & INN1 & $0.981 * * *$ & \multirow{2}{*}{0.98} & \multirow{2}{*}{0.961} & \multirow{2}{*}{0.96} & \multirow{2}{*}{ Yes } \\
\hline & INN2 & $0.981 * * *$ & & & & \\
\hline \multirow{3}{*}{ PAS } & PAS1 & $0.791 * * *$ & \multirow{3}{*}{0.91} & \multirow{3}{*}{0.850} & \multirow{3}{*}{0.77} & \multirow{3}{*}{ Yes } \\
\hline & PAS2 & $0.914 * * *$ & & & & \\
\hline & PAS3 & $0.917 * * *$ & & & & \\
\hline
\end{tabular}

\subsection{Evaluation of structural model}

According structural model path coefficients in Fig.2 and Table2, as one of the latent variables reflecting the traffic hub effect, PAS has a highly significant effect on ABS supporting H2, ABS has a highly significant effect on INN and EDE supporting $\mathrm{H} 3$ and $\mathrm{H} 4$, INN has a highly significant effect on EDE supporting H1. FRE is another latent variable reflecting the traffic hub effect, which has a highly significant effect on EDE supporting
H5b. However, the direct effect of FRE on INN is not significant not supporting H6. In addition, the direct effect of PAS on EDE is not significant.

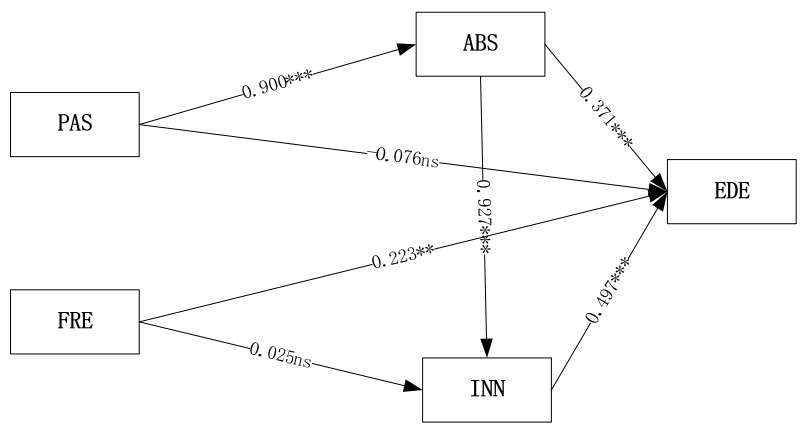

Fig.2. Results of structural model

Note: $* * *$ significant at $\mathrm{p}=0.01$ level; $* *$ significant at $\mathrm{p}=0.05$ level; n.s. Not-significant.

Table 2. Path coefficients and hypotheses test

\begin{tabular}{|c|c|c|c|c|c|}
\hline & $\begin{array}{l}\text { Path } \\
\text { coeffici } \\
\text { ents }\end{array}$ & $\begin{array}{l}\mathrm{T} \\
\text { Statistics }\end{array}$ & $\begin{array}{l}95 \% \\
\text { Confidence } \\
\text { interval }\end{array}$ & $\begin{array}{l}\text { Hypot } \\
\text { heses }\end{array}$ & Remarks \\
\hline $\begin{array}{l}\mathrm{PAS} \rightarrow \\
\mathrm{ABS}\end{array}$ & 0.900 & $29.390 * * *$ & $(0.850,0.963)$ & H2 & Supported \\
\hline $\begin{array}{l}\mathrm{PAS} \rightarrow \\
\mathrm{EDE}\end{array}$ & -0.076 & $1.023 \mathrm{~ns}$ & $(-0.233,0.067)$ & & \\
\hline $\begin{array}{l}\mathrm{FRE} \rightarrow \\
\mathrm{EDE}\end{array}$ & 0.223 & $2.315^{* *}$ & $(-0.034,0.328)$ & H5b & Supported \\
\hline $\begin{array}{l}\mathrm{FRE} \rightarrow \\
\mathrm{INN}\end{array}$ & 0.025 & 0.291 & $(-0.074,0.269)$ & H6 & $\begin{array}{l}\text { Not } \\
\text { supported }\end{array}$ \\
\hline $\begin{array}{l}\mathrm{ABS} \rightarrow \\
\mathrm{EDE}\end{array}$ & 0.371 & $3.261 * * *$ & $(0.177,0.640)$ & H4 & Supported \\
\hline $\begin{array}{l}\mathrm{ABS} \rightarrow \\
\mathrm{INN}\end{array}$ & 0.927 & $12.583 * * *$ & $(0.710,1.000)$ & H3 & Supported \\
\hline $\begin{array}{l}\mathrm{INN} \rightarrow \\
\mathrm{EDE}\end{array}$ & 0.497 & $6.244 * * *$ & $(0.354,0.666)$ & H1 & Supported \\
\hline
\end{tabular}

\subsection{Tests for mediation}

This study uses non-parametric bootstrapping method to evaluate the significance of mediating effect ${ }^{[34]}$. The only requirement for mediation is that the indirect effect has to be significant. If the indirect effect is significant, the mediator absorbs some of the direct effect ${ }^{[34]}$. In this study, the direct effect between PAS and EDE is not significant, but two indirect effects are significant $(\beta 1=$ $\left.0.334 * * *, \mathrm{t}=3.097 ; \beta 2=0.415^{* * *}, \mathrm{t}=5.732 ;\right)$, and the total effect is significant. This leads to conclude that indirect mediation between PAS and EDE through ABS and INN exists, H5a is supported. In Table3 , bootstrapping procedure are used and complete the assessment of mediator, Variance-Account-For (VAF) determines the size of the indirect effect relative to the total effect ${ }^{[34]}$.

Table3. Indirect effect and hypotheses test

\begin{tabular}{|c|c|c|c|c|c|c|}
\hline & $\begin{array}{l}\text { Direct effect } \\
\text { (t-value) }\end{array}$ & $\begin{array}{l}\text { Indirect effect } \\
\text { (t-value) }\end{array}$ & $\begin{array}{l}\text { Total indirect effect } \\
(\mathrm{t} \text {-value })\end{array}$ & $\begin{array}{l}\text { Total effect } \\
\text { (t-value) }\end{array}$ & VAF (\%) & Conclusion \\
\hline $\mathrm{PAS} \rightarrow \mathrm{ABS} \rightarrow \mathrm{EDE}$ & $\begin{array}{c}-0.076 \\
(1.023 \mathrm{~ns})\end{array}$ & $\begin{array}{c}0.334 \\
\left(3.09^{* * *}\right)\end{array}$ & $\begin{array}{c}0.749 \\
(8.743 * * *)\end{array}$ & $\begin{array}{c}0.674 \\
\left(9.341^{* * *}\right)\end{array}$ & $100 \%$ & H5a Supported \\
\hline
\end{tabular}




\begin{tabular}{|c|c|c|c|c|c|c|}
\hline $\mathrm{PAS} \rightarrow \mathrm{ABS} \rightarrow \mathrm{INN} \rightarrow \mathrm{EDE}$ & & $\begin{array}{c}0.415 \\
(5.73 * * *)\end{array}$ & & & & H5a Supported \\
\hline $\mathrm{FRE} \rightarrow \mathrm{INN} \rightarrow \mathrm{EDE}$ & $\begin{array}{c}0.223 \\
\left(2.315^{* *}\right)\end{array}$ & $\begin{array}{c}0.012 \\
(0.262 \mathrm{~ns})\end{array}$ & $\begin{array}{c}0.012 \\
(0.262 \mathrm{~ns})\end{array}$ & $\begin{array}{c}0.235 \\
\left(2.548^{* *}\right)\end{array}$ & $5.12 \%$ & \\
\hline
\end{tabular}

\section{Conclusion and discussion}

According to the empirical analysis of urban data in China, it is found that urban knowledge absorptive and innovative capacity play an intermediary role.

First of all, based on the analysis of urban passenger volume data, it is found that the direct influence of people flow effect on urban economic development is not significant, and the improvement of urban knowledge absorptive and innovative capacity caused by the people flow effect are the main reasons promoting economic development. In other words, if a city does not gather enough innovation elements and is not attractive enough, urban passenger volume may only show the outflow of labor to surrounding cities, which is not conducive to the economic development of cities.

Secondly, based on the analysis of the urban freight volume data, it is found that the logistics effect has a promotion role on the urban economic development, but does not have a significant promotion on innovation. This conclusion is not satisfactory, but after careful consideration, it can be found that if the increase of freight volume is based on the development of the urban own industry, then the development of industry will undoubtedly promote the urban innovation. However, if a city has not enough human capital accumulation, knowledge absorptive capacity and industrial development foundation, then the freight volume of the city may be mainly freight turnover volume, which cannot pull urban innovation effectively.

Thirdly, from the mediating effect of urban knowledge absorption ability and innovation ability, the joint mediating effect from knowledge absorption and technological innovation process is greater than the knowledge absorption itself, which further illustrates the importance of knowledge transformation in urban innovation.

Fourth, the structure model above does not show the relationships between PAS and INN, FRE and ABS, because the relationships between them is not significant. This shows that the increase of passenger volume cannot promote technological innovation directly without the increase of absorption capacity. On the other hand, it also shows that the freight volume cannot influence on the absorption capacity based on human capital accumulation directly.

To sum up, the influences of urban traffic hub effect on economic development is shown in the following figure (Fig.3).

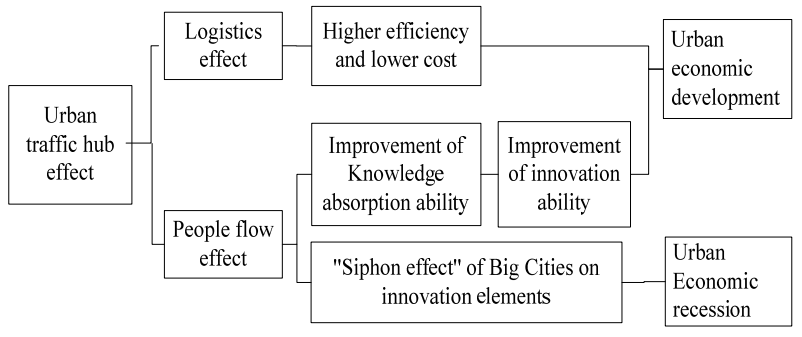

Fig.3. Urban traffic hub effect and economic development

\section{Acknowledgements}

This paper is supported by Program for Innovative Research Team (in Science and Technology) in University of Henan Province of China (Grant No. 19IRTSTHN016), National Social Science Foundation of China (Grant No. 17BJL056).

\section{References}

1. Rostow, W.W. The stages of economic growth: a non-communist manifesto . Cambridge: Cambridge University Press (1960)

2. Aschauer, D. A . Is public expenditure productive . Journal of Monetary Economics , 23(2):177-200 (1989)

3. Donaldson, D . Railroads of the raj: estimating the impact of transportation infrastructure. American Economic Review, 108(4/5):899-934 (2010)

4. Baum-Snow, N. Did highways cause suburbanization. The Quarterly Journal of Economics, 122(2):775-805 (2007)

5. Myrdal, G. Economic Theory and Underdeveloped Regions. London, Gerald Duckworth, p.168 (1957)

6. Jacobs, J. The economy of cities. New York: Vintage (1969)

7. Lucas, R. E. On the mechanics of economic development. Journal of Monetary Economics, volume 22, 38-39 (1998)

8. Olivier Crevoisier. Innovation and the City. Published in E.J. Malecki and P. Oinas (Eds.), Making connections: technological learning and regional economic change, Ashgate Publishing Company, 61-77 (1999)

9. Maillat, D., Crevoisier, O. and Lecoq, B. 1991. Reseau d'innovation et dynamique territorial. Un essai de typologie, Revue d'Economie Regionale et Urbaine, NO. 3-4, pp. 407-432 
10. Boyd Cohen, Esteve Almirall1 and Henry Chesbrough. The City as a Lab: Open Innovation Meets the Collaborative Economy. California Management Review, Vol. 59(1): 5-13 (2016)

11. Liu, S.L., Hu, A.G. Transportation infrastructure and Economic Growth: A perspective of China's regional Disparities. China Industrial Economics, (04):14-23 (2010)

12. Zhang, X.L. Does China's transport Infrastructure promote regional economic growth? -- on the Spatial Spillover effect of Transport Infrastructure. Social Sciences in China, (3):60-77 (2012)

13. Feng,W., Xu,K.N. Transportation infrastructure and economic growth: a literature review. Industrial Economic Review, (3):61-70 (2013

14. Li, X.S., Sun, B.W. Does the opening of high-speed rail promote regional manufacturing agglomeration? ---quasi-natural experimental research based on Beijing-Guangzhou high-speed railway. China Soft Science, (7): 81-90 (2017)

15. Liu, Y.Z., Li, Y. High-speed railway construction and urban economic growth in China. Financial Research, (11): 18-33(2017)

16. Li, X.Z., Ji, X.L., Zhou, L.L. Can high-speed rail improve corporate resource allocation? -- Evidence from China's industrial enterprise database and highspeed railway geographic data. Economic Review, (6): 3-21(2017)

17. Sands, B . The development effects of high-speed rail stations and implications for California . Sacramento: California High Speed R ail Series, Berkely University of California, pp. 257-284(1993)

18. Chen, C. L., Hall, P . The impacts of high-speed trains on British economic geography: a study of the UK's intercity $125 / 225$ and its effects. Journal of Transport Geography, 19(4) : 689-704(2011)

19. Krugman. Increasing returns and economic geography . Journal of Political Geography , 99:183-199(1991)

20. Chen, C. L., Hall, P . The Wider Spatial-economic Impacts of High-speed Trains: A Comparative Case Study of Manchester and Lille Subregions . Journal of Transport Geography, 24( 4) : 89-110(2012)

21. Liu, F. High-speed rail, knowledge spill over and urban innovation and development -- evidence from 278 cities in China. Finance and Trade Research, (4): 14-29(2019)

22. Wei, G.D., Li, X.M. Research on the Influence of high-speed railway knowledge spillover on tertiary industry agglomeration: An empirical study based on the Yangtze River Delta urban agglomeration. Inquiry into Economic Issues, (2): 130-136(2019)
23. Yang, S.Y., Li, Z. The opening of high-speed railway and urban innovation. Finance and Economics, (1): 87-99(2019)

24. Du, X.Q., Peng, M.W. Will the opening of highspeed railway promote the flow of senior talents? Business Management Journal, (12): 89-107(2017)

25. Antonio K.W., Lau A., William L. Regional innovation system, absorptive capacity and innovation performance: An empirical study. Technological Forecasting \& Social Change, (92) :99-114(2015)

26. Vickerman,R. High-speed rail and regional development: the case of intermediate stations . Journal of Transport Geography, 42(6) : 157-165(2015)

27. Gutiérrez, J., Gonzalez, R., \& Gomez, G. The European high-speed train network: predicted effects on accessibility patterns. Journal of transport geography, 4(4):227-238(1996)

28. Wang, Y.J., Yu, W. Research on spatial measurement of convergence of inter-provincial innovation TFP in China. Journal of Shandong University (Philosophy and Social Sciences edition), (01):43-49(2017)

29. Chen, J. Research on knowledge management and knowledge service in the construction of smart city. Posts and Telecom Press Co., LTD(2015)

30. Glenn Athey, Max Nathan, Chris Webber \& Sami Mahroum. Innovation and the city, Innovation, 10:156-169(2008)

31. Hoong Chor Chin, Mohammed Abdul Quddus. Applying the random effect negative binomial model to examine traffic accident occurrence at signalized intersections, 35(2):253-259(2003)

32. AITIELU. China's ranking of arrivals and departures of major railway stations (HSR) in 2018. [online] available for < http: //www.aitielu.cn/? s $=\% \mathrm{E} 5 \% 90 \% 84 \% \mathrm{E} 5 \% \mathrm{~A} 4 \% \mathrm{~A} 7 \% \mathrm{E} 7 \% 81 \% \mathrm{AB} \% \mathrm{E} 8 \%$ BD $\%$ A6\% $\% 7 \%$ AB $\% 99 \% \mathrm{EF} \% \mathrm{BC} \% 88 \% \mathrm{E} 9 \% \mathrm{AB} \% 9$ $8 \% \mathrm{E} 9 \% 93 \% 81 \% \mathrm{E} 7 \% \mathrm{AB} \% 99 \% \mathrm{EF} \% \mathrm{BC} \% 89 \% \mathrm{E} \%$ $88 \% \mathrm{~B} 0 \% \mathrm{E} 5 \% 8 \mathrm{~F} \% 91 \% \mathrm{E} 8 \% \mathrm{BD} \% \mathrm{~A} 6 \% \mathrm{E} 6 \% \mathrm{AC} \% \mathrm{~A} 1$ \&submit $=>$ [Accessed at 30/July/2020](2019)

33. Jöreskog, K. G. Simultaneous factor analysis in several populations. Psychometrika, 36(4):409426(1971)

34. Fornell, C., \& Larcker, D. F. Structural equation models with unobservable variables and measurement error: Algebra and statistics. Journal of Marketing Research,18(1): 382-388(1981) 